Economics Development Analysis Journal 6(2)(2017) Economics Development Analysis Journal

\title{
Analisis Kondisi Sosial Ekonomi Masyarakat Terhadap Ketersediaan Sanitasi
}

\author{
Erika Rizqyana Budi ${ }^{\bowtie}$
}

Jurusan Ekonomi Pembangunan, Fakultas Ekonomi, Universitas Negeri Semarang

\begin{tabular}{l}
\hline Info Artikel \\
\hline Sejarah Artikel: \\
Diterima Januari 2017 \\
Disetujui Maret 2017 \\
Dipublikasikan Mei 2017 \\
\hline Keywords: \\
Sanitation Availability, \\
Household Expenditure, \\
Healthy Information, \\
Society Behavior \\
\hline
\end{tabular}

\begin{abstract}
Abstrak
Ketersediaan sanitasi merupakan salah satu bagian dari kebutuhan kesehatan, dengan sanitasi yang layak akan menciptakan individu yang sehat dan meningkatkan kualitas sumber daya manusia. Keputusan rumah tangga untuk dapat menikmati akses terhadap sanitasi sangat bergantung pada kondisi sosial ekonomi. Tujuan dari penelitian ini yaitu untuk menganalisis faktor sosial ekonomi terhadap ketersediaan sanitasi di Kecamatan Suruh, Kabupaten Semarang. Penelitian ini menggunakan data primer dengan 100 responden dan menggunakan analisis regresi logistik. Variabel dalam penelitian ini yaitu sanitasi, pengeluaran rumah tangga, informasi kesehatan, dan perilaku masyarakat. Kesimpulan dari hasil penelitian ini yaitu bahwa pengeluaran rumah tangga dan perilaku masyarakat berpengaruh signifikan terhadap ketersediaan sanitasi sedangkan informasi kesehatan tidak berpengaruh signifikan terhadap ketersediaan sanitasi.
\end{abstract}

\section{Abstract}

Sanitation availability is part of healthy needs. By suitable sanitation, it will increase the human resource quality. Household desision to access sanitation depends on social economy condition. This study aims to analyze the social and economy factors influence the sanitation availability in Suruh Subdistrict, Semarang Regency. This study uses primary data which collected from 100 households and analyzed by logistic regression. The variables are sanitation, household expenditure, healthy information, and society behavior. The result shows that household expenditure and household behavior significantly affect the sanitation availability while healthy information unsifnificantly affect the sanitation availability.

\footnotetext{
बAlamat korespondensi:

Gedung L2 Lantai 2 FE Unnes

Kampus Sekaran, Gunungpati, Semarang, 50229

E-mail: erikarizqyana88@gmail.com
} 


\section{PENDAHULUAN}

Kualitas sumber daya manusia ditandai dengan meningkatnya kesehatan, taraf pendidikan masyarakat, angka harapan hidup, serta akses sumber daya untuk hidup layak. Kesehatan masyarakat menjadi investasi penting bagi suatu negara, dengan terjaminnya kualitas kesehatan maka membantu setiap orang untuk hidup produktif secara sosial dan ekonomi.

Pemenuhan kebutuhan akan air bersih terutama untuk minum dan sanitasi masih menjadi salah satu persoalan yang tidak terselesaikan bagi Negara Indonesia. Menurut WHO dan UNICEF tahun 2014 terdapat 54 juta orang Indonesia yang melakukan buang air besar sembarangan dilihat dari taraf kesehatan, hal tersebut menjadi salah satu yang mempengaruhi kualitas hidup manusia. Tahun 2013 jumlah rumah tangga di Indonesia menurut Badan Pusat Statistik yang telah memiliki fasilitas sanitasi yang sehat dan layak hanya sebesar $59,71 \%$. Perencanaan kebijakan yang tept dapat dilakukan untuk memperbaiki akses sanitasi yang berkelanjutan (Munamati, et al, 2016).

Sanitasi yang buruk dapat menjadi silent disaster atau bencana diam-diam, yang akan terlihat dari kemiskinan dan ketimpangan besar seperti yang terjadi di dunia saat ini. Akses dan sanitasi dapat menentukan kesehatan rumah tangga (Correa, et al, 2016). Program Air dan Sanitasi Bank Dunia tahun 2013, menilai dampak ekonomi tahunan dari sanitasi yang buruk salah satunya di Negara Indonesia adalah kehilangan Rp56 triliun atau US\$ 6,3 miliar sekitar 2,3\% dari GDP per tahun. Biaya kesehatan per tahun akibat sanitasi buruk mencapai Rp139.000 per orang atau Rp31 triliun secara nasional.

Menurut Direktur Perumahan dan Permukiman Badan Perencanaan Pembangunan Nasional, Nugroho Tri Utomo tahun 2015 bahwa sanitasi yang layak bermanfaat bagi pembangunan diantaranya mempengaruhi pertumbuhan ekonomi dan menurunkan angka kemiskinan karena jika kondisi sanitasi buruk maka rata-rata keluarga di Indonesia harus menanggung biaya 1,25 juta setiap tahunnya mencakup biaya perawatan, berobat, serta hilangnya pendapatan yang seharusnya diterima (opportunity cost) tentunya hal tersebut sangat berat untuk ditanggung bagi rumah tangga miskin. Manfaat yang lainnya yaitu dapat menjaga lingkungan hidup, menurut Bank Pembangunan Asia tahun 2009 bahwa kita gagal menginvestasikan USD 1 untuk menangani sanitasi sehingga sungai tercemar maka untuk memulihkan kembali kondisi air tersebut diperlukan pengeluaran biaya sebesar USD 36.

Kabupaten Semarang merupakan Kabupaten yang mewakili Kabupaten/Kota di Provinsi Jawa Tengah dalam program pemerataan sanitasi bagi seluruh masyarakat. Tidak hanya memperoleh bantuan dari STBM tetapi juga bekerja sama dengan Indonesian Urban Water, Sanitation, and Hygiene (IUWASH) yang didanai oleh Badan Pembangunan Internasional Amerika Serikat. Kondisi sanitasi Kabupaten Semarang pada tahun 2013 dibagi menjadi 3 kategori, yaitu dearah dengan kategori beresiko sangat tinggi ada 10 desa, daerah dengan resiko tinggi $182 \mathrm{desa} /$ keluarahan, serta daerah dengan resiko sedang terdapat 43 desa/keluarahan.

Meskipun ketersediaan sanitasi di Kabupaten Semarang menunjukkan setiap tahunnya ada peningkatan ketersediaan fasilitas tempat buang air besar milik pribadi maupun fasilitas tempat buang air besar milik bersama. Peningkatan kepemilikan sanitasi milik sendiri bukan berarti mampu menyelesaikan permasalahan perilaku buang air besar sembarangan, sebab fenomena yang terjadi di masyarakat masih banyak yang melakukan perilaku buang air besar sembarangan baik secara terbuka maupun terselubung disebabkan masyarakat yang belum mampu mengubah kebiasaan untuk melakukan perilaku hidup bersih dan sehat. Tanpa akses terhadap sanitasi, masyarakat memiliki resiko tertular penyakit yang tinggi (Zakaria, et al, 2015).

Sanitasi yang buruk terjadi di Kabupaten Semarang dapat dipengaruhi oleh faktor sosial ekonomi. Menurut Hermawan (2005:3), banyak faktor yang menjadi penyebab menurunnya kualitas lingkungan diantaranya yaitu rendahnya tingkat pendidikan dan pengetahuan masyarakat 
tentang lingkungan sehingga mereka kurang respon untuk dapat menerima informasi yang bermanfaat bagi dirinya. Menurut Green dalam Notoatmodjo (2007:17), bahwa yang paling mempengaruhi kesehatan seseorang adalah perilaku dan faktor non perilaku. Sehingga faktor sosial yang mempengaruhi ketersediaan sanitasi masyarakat diwakilkan oleh informasi kesehatan dan perilaku masyarakat.

Sedangkan menurut Joko \& Elanda Fikri (2012:49) bahwa masalah ekonomi sangat erat hubungannya dengan kemampuan penduduk untuk membangun fasilitas sanitasi yang sehat. Walaupun tingkat pengetahuan teknis sudah memadai dan sudah menyadari betapa pentingnya memiliki fasilitas sanitasi yang sehat, namun apabila kondisi ekonomi keluarga tersebut lemah. Maka masyarakat akan tetap menggunakan fasilitas sanitasi yang buruk dan kondisi ini akan berpotensi untuk mencemari lingkungan. Sehingga pengeluaran rumah tangga yang diperoleh dari pendapatan sebelumnya menjadi salah satu faktor ekonomi yang mewakili ketersediaan sanitasi masyarakat.

Sanitasi menjadi bagian infrastruktur permukiman yang dalam mewujudkannya dipengaruhi keputusan ekonomi masyarakat karena mempengaruhi kondisi sosial ekonomi masyarakat di suatu daerah. Sedangkan menurut (Rahman, 2010:73) infrastruktur desa melalui Program Penanggulangan Kemisikinan Perkotaan (P2KP) salah satunya pembangunan jalan desa dapat menggerakkan perekonomian desa.

Tabel. 1. Rumah Tangga Belum Memiliki Sanitasi Dasar Menurut Kecamatan di Kabupaten Semarang Tahun 2010-2014

\begin{tabular}{|c|c|c|c|c|c|c|}
\hline Kecamatan & 2010 & 2011 & 2012 & 2013 & 2014 & Ranking \\
\hline Getasan & 980 & 986 & 988 & 995 & 995 & 17 \\
\hline Tengaran & 1.149 & 1.154 & 1.158 & 1.159 & 1.163 & 15 \\
\hline Susukan & 1.626 & 1.630 & 1.638 & 1.642 & 1.647 & 9 \\
\hline Kaliwungu & 1.240 & 1.243 & 1.249 & 1.252 & 1.255 & 14 \\
\hline Suruh & 3.807 & 3.825 & 3.840 & 3.853 & 3.862 & 1 \\
\hline Pabelan & 2.637 & 2.647 & 2.658 & 2.677 & 2.692 & 4 \\
\hline Tuntang & 1.865 & 1.877 & 1.885 & 1.901 & 1.908 & 6 \\
\hline Banyubiru & 1.333 & 1.316 & 1.322 & 1.329 & 1.334 & 11 \\
\hline Jambu & 367 & 369 & 370 & 371 & 371 & 19 \\
\hline Sumowono & 1.072 & 1.078 & 1.080 & 1.093 & 1.106 & 16 \\
\hline Ambarawa & 1.279 & 1.286 & 1.291 & 1.295 & 1.300 & 13 \\
\hline Bandungan & 1.697 & 1.715 & 1.721 & 1.734 & 1.746 & 8 \\
\hline Bawen & 1.279 & 1.290 & 1.297 & 1.312 & 1.331 & 12 \\
\hline Bringin & 3.689 & 3.702 & 3.716 & 3.723 & 3.746 & 2 \\
\hline Bancak & 2.366 & 2.389 & 2.400 & 2.411 & 2.420 & 5 \\
\hline Pringapus & 3.075 & 3.096 & 3.108 & 3.133 & 3.154 & 3 \\
\hline Bergas & 1.331 & 1.345 & 1.350 & 1.360 & 1.372 & 10 \\
\hline Ungaran Barat & 877 & 887 & 891 & 899 & 911 & 18 \\
\hline Ungaran Timur & 1.830 & 1.837 & 1.844 & 1.847 & 1.851 & 7 \\
\hline Total & 33.499 & 33.672 & 33.806 & 33.986 & 34.164 & \\
\hline
\end{tabular}

Sumber: Data Strategis Kecamatan 2015 (diolah).

Pada tabel di atas Kecamatan Suruh menempati peringkat pertama dengan jumlah masyarakat yang belum memperoleh akses sanitasi paling tinggi dibandingkan 19 Kecamatan di Kabupaten Semarang lainnya. Hal ini disebabkan karena masih banyaknya masyarakat dengan pendidikan yang rendah, keterbatasan pendapatan rumah tangga serta akses daerahnya yang terpencil berada di perbatasan antara Kecamatan Suruh dengan Kabupaten Boyolali. Sehingga rumah tangga masih banyak yang melakukan perilaku buang 
air besar sembarangan serta mengandalkan air bersih berasal dari sumur dan sungai.

Berdasarkan latar belakang yang telah diuraikan di atas, maka rumusan masalah dalam penelitian ini adalah bagaimana pengaruh pengeluaran rumah tangga, pengaruh informasi kesehatan, dan perilaku masyarakat terhadap ketersediaan sanitasi di Kecamatan Suruh Kabupaten Semarang. Adapun tujuan dari penelitian ini adalah mengetahui pengaruh pengeluaran rumah tangga, pengaruh informasi kesehatan, dan perilaku masyarakat terhadap ketersediaan sanitasi di Kecamatan Suruh Kabupaten Semarang.

$$
\begin{aligned}
\mathrm{n}=\frac{\mathrm{N}}{1+\mathrm{Ne}^{2}} & = \\
& =
\end{aligned}
$$

Sedangkan sampel adalah suatu bagian dari populasi tertentu yang menjadi perhatian. Teknik yang digunakan untuk mengambil sampel yaitu teknik proportional sampling. Teknik proportional sampling merupakan mengambil sampel dari setiap sub populasi dengan memperhitungkan besar kecilnya sub populasi tersebut.

\section{Variabel Penelitian dan Definisi Operasional Definisi Variabel Terikat (Y): Sanitasi}

Sanitasi dalam penelitian ini adalah ketersediaan fasilitas buang air besar (MCK) yang dinyatakan dalam satuan unit setiap rumah tangga di Kecamatan Suruh, Kabupaten Semarang.

\section{Definisi Variabel Bebas \\ Pengeluaran Rumah Tangga $\left(X_{1}\right)$}

Pengeluaran rumah tangga yang dinyatakan dalam satuan rupiah merupakan nilai pembelanjaan yang dilakukan setiap rumah tangga di Kecamatan Suruh Kabupaten Semarang untuk memenuhi kebutuhannya seperti sandang, pangan, papan, kesehatan, pendidikan dan sebagainya.

Informasi kesehatan dalam penelitian ini yaitu berbagai sumber informasi kesehatan yang diperoleh masyarakat di Kecamatan Suruh Kabupaten Semarang sehingga memberikan

\section{METODE PENELITIAN}

\section{Jenis dan Sumber Data}

Jenis penelitian ini yaitu pengamatan langsung terhadap objek yang diteliti di lapangan dengan mengambil informasi dari sumber pertama baik individu atau perseorangan, seperti hasil wawancara atau pengisian kuesioner.

\section{Populasi, Sampel, dan Teknik Sampling}

Populasi dalam penelitian ini adalah rumah tangga di Kecamatan Suruh sebanyak 21.639. Menurut Slovin untuk menentukan besarnya sampel dicari dengan rumus:

21.639

$1+\left(21.639 \times 0,1^{2}\right)$

99,53 (dibulatkan 100 responden)

pemahaman dan pengetahuan mengenai sanitasi.

\section{Perilaku Masyarakat $\left(\mathrm{X}_{3}\right)$}

Perilaku masyarakat pada penelitian ini yaitu perilaku individu di Kecamatan Suruh Kabupaten Semarang dalam melakukan pembuangan kotoran manusia atau bahan buangan berbahaya lainnya bagi kesehatan manusia, dan perilaku setiap individu dalam menjaga lingkungan sekitar.

\section{Regresi Logistik}

Analisis regresi logistik digunakan untuk menjelaskan hubungan antara variabel respon yang berupa data dikotomik/biner dengan variabel bebas yang berupa data berskala interval dan atau kategorik (Hosmer dan Lemeshow, 2000:16). Variabel yang dikotomik/ biner adalah variabel yang hanya mempunyai dua kategori saja, yaitu kategori yang menyatakan kejadian sukses $(Y=1)$ dan kategori yang menyatakan kejadian gagal $(\mathrm{Y}=0)$.

\section{HASIL DAN PEMBAHASAN}

\section{Karakteristik Responden Berdasarkan Ketersediaan Sanitasi}

Bahwa 43\% responden di Kecamatan Suruh belum mendapatkan akses sanitasi yang layak seperti ketersediaan jamban/ MCK 
(Mandi Cuci Kakus). Sedangkan sisanya yaitu $57 \%$ responden telah memiliki MCK pribadi. Kondisi masih ditemukannya rumah tangga yang belum memiliki MCK pribadi, menunjukkan jika masyarakat masih melakukan perilaku buang air besar sembarangan seperti di sungai, saluran irigasi, dan sebagainya yang dianggap bukan menjadi tempat penampungan kotoran manusia/ tinja yang layak sesuai standar yang ditentukan oleh Dinas Kesehatan. Sebesar $68 \%$ belum memiliki sarana pembuangan air limbah. Sarana pembuangan air limbah sangat penting bagi rumah tangga karena fungsinya sebagai penampung atau sebagai tempat pembuangan limbah yang dihasilkan oleh rumah tangga setiap hari. Kelurahan Dadapayam mendominasi masyarakat yang belum menjangkau akses sanitasi dasar seperti MCK. Hal tersebut disebabkan karena masyarakat yang sebagian besar masih berpendidikan rendah, akses sosial ekonomi yang terbatas bahkan tidak jarang masyarakat lebih memilih untuk menikmati sarana sosial ekonomi di Kabupaten Boyolali dibandingkan di daerah Kecamatan Suruh karena letak geografisnya yang berbatasan langsung dengan Kabupaten Boyolali.

\section{Karakteristik Responden Berdasarkan Pengeluaran Rumah Tangga}

Karakteristik responden berdasarkan pengeluaran rumah tangga menunjukkan jika pendapatan yang diterima masyarakat sebagian besar berkisar antara Rp1.000.000- Rp1.499.000. Sehingga alokasi pengeluaran rumah tangga untuk perawatan sanitasi masih sangat terbatas dilihat dari $78 \%$ responden yang menyatakan jika pendapatan keluarga yang digunakan untuk merawat sanitasi masih dibawah Rp499.000.
Alokasi biaya kesehatan masih banyak rumah tangga yang mengalokasikan dari pendapatan sendiri dan belum bergabung pada program Pemerintah seperti BPJS (Badan Penyelenggara Jaminan Sosial).

\section{Karakteristik Responden Berdasarkan Informasi Kesehatan}

Karakteristik responden berdasarkan informasi kesehatan, dan hanya $42 \%$ masyarakat yang memperoleh informasi secara langsung dari petugas kesehatan. Kondisi ini menggambarkan jika peran petugas kesehatan dalam menyampaikan atau memberi informasi mengenai kesehatan khususnya sanitasi masih terbatas. Motivasi masyarakat dalam menerapkan perilaku hidup sehat sebesar 57\% masih dipengaruhi oleh lingkungan sekitar. Sedangkan sisanya telah menerapkan perilaku hidup sehat karena mengetahui pentingnya sanitasi bagi kelangsungan hidup dan standar kualitas hidupnya.

\section{Karakteristik Responden Berdasarkan Perilaku Masyarakat}

Karakteristik responden berdasarkan perilaku masyarakat bahwa $57 \%$ masyarakat telah membuang tinja septic tank, namun $43 \%$ responden masih membuang kotoran manusia/ tinja di kolam, sungai, saluran irigasi, dan sebagainya. Perilaku masyarakat dalam menjaga kesehatan lingkungan salah satunya melalui kegiatan kerja bakti masih belum sepenuhnya dilaksanakan, ditunjukkan dengan 51\% responden yang menjawab jarang atau bahkan tidak adanya kegiatan bersih bersama.

\section{Pengujian Hipotesis}

Tabel 2. Hasil Regresi Logistik

\begin{tabular}{llll}
\hline X1 (Pengeluaran RT) & 0,0190 & Prob(LR statistic) & 0,000000 \\
X2 (Informasi Kesehatan) & 0,9879 & Mean dependent var & 0,570000 \\
X3 (Perilaku Masyarakat) & 0,0003 & S.E. of regression & 0,129755 \\
C & 0,2089 & Log likelihood & $-6,326379$ \\
McFadden R-squared & 0,907416 & Deviance & 12,65276 \\
S.D. dependent var & 0,497570 & Restr. Log likelihood & $-68,33149$ \\
LR statistic & 124,0102 & Avg. Log likelihood & $-0,063264$ \\
\hline Total obs =100 & & \\
Obs with Dep = (43) & & Obs with Dep = 1 (57) & \\
\hline
\end{tabular}

Sumber: Data primer, diolah. 


$$
Y=\operatorname{Ln} \frac{P}{1-p}=0,2089+0,0190+0,9879+0,0003+\mu_{i}
$$

Berikut ini adalah hasil variabel yang dianggap berpengaruh terhadap kepemilikan sanitasi di Kecamatan Suruh Kabupaten Semarang, antara lain:

\section{Pengeluaran Rumah Tangga Terhadap Ketersediaan Sanitasi}

Pengeluaran rumah tangga berpengaruh terhadap ketersediaan sanitasi, dilihat dari probabiliitas $\mathrm{X}_{1}$ sebesar 0,0190. Pengeluaran rumah tangga yang diperoleh dari pendapatan yang diterima masing-masing rumah tangga meningkat maka memberikan kemungkinan ketersediaan sanitasi rumah tangga ikut meningkat. Ini merupakan suatu konsekuensi logis karena dengan kondisi keuangan yang lebih mapan dan telah mampu memenuhi kebutuhan pangan dengan baik tentu mempunyai daya beli yang lebih tinggi. Sehingga alokasi pengeluaran rumah tangga untuk memiliki sanitasi juga semakin berpeluang besar.

Maka jika dilihat dari kondisi Kecamatan Suruh sebagian besar rumah tangga memiliki pendapatan dibawah upah minimum regional Kabupaten Semarang dengan mata pencaharian sebagai petani yang hanya menikmati hasil panen dua kali dalam satu tahun. Hal tersebut berpengaruh pada kualitas pemenuhan kebutuhan setiap harinya seperti sandang, pangan, papan, pendidikan, kesehatan dan sebagainya.

Pada teori Engel bahwa semakin tinggi tingkat pendapatan maka persentase pengeluaran rumah tangga untuk konsumsi pangan akan mengalami penurunan. Maka keluarga dapat dikatakan sejahtera apabila persentase pengeluaran untuk konsumsi pangan jauh lebih rendah daripada pengeluaran non pangan. Artinya, setiap tambahan pendapatan yang diperoleh akan dialokasikan untuk memenuhi kebutuhan non pangan.

Kebutuhan non pangan dapat diartikan sebagai kebutuhan sekunder atau kebutuhan primer. Jika masyarakat telah mampu memenuhi kebutuhan pangan setiap harinya, maka sisa pendapatan dialokasikan pada sarana yang menunjang taraf kesejahteraan seperti kesehatan sebab hal tersebut dirasa sudah menjadi prioritas dalam hidupnya. Mewujudkan prioritas kesehatan dengan meningkatkan ketersediaan sarana sanitasi. Pengeluaran rumah tangga untuk sanitasi sebagai upaya pencegahan penyakit agar masyarakat tidak mengeluarkan biaya kesehatan untuk berobat dan mencegah dampak sosial ekonomi lainnya akibat sanitasi yang buruk.

\section{Informasi Kesehatan Terhadap Ketersediaan Sanitasi}

Informasi kesehatan tidak berpengaruh terhadap ketersediaan sanitasi, dilihat dari probabiliitas $\mathrm{X}_{2}$ sebesar 0,9879 . Informasi kesehatan yang diperoleh setiap rumah tangga pasti berbeda, rumah tangga dengan jenjang pendidikan tinggi serta berbagai sumber informasi yang dapat diperoleh dengan mudah memberikan pengetahuan yang lebih baik dibandingkan rumah tangga dengan sumber informasi kesehatan yang terbatas.

Informasi kesehatan yang diperoleh dari tenaga profesional seperti tenaga kesehatan juga berpengaruh pada peningkatan pemahaman masyarakat akan ketersediaan sanitasi dasar di tempat tinggal. Namun jumlah tenaga kesehatan yang tersedia belum merata di seluruh Kecamatan Suruh, dilihat dari jumlah tenaga kesehatan yang setiap tahunnya tidak banyak mengalami perubahan dan hanya terpusat di Kelurahan Suruh sehingga masih banyak Kelurahan yang belum memiliki tenaga kesehatan. Berdampak pada pemahaman masyarakat yang rendah dan belum mampu mengubah kebiasaannya untuk mengaplikasikan hidup sehat. Informasi kesehatan yang disalurkan melalui media sosialisasi atau media pengenalan lainnya sangat penting dilakukan sebagai pendekatan pada masyarakat untuk lebih menciptakan kesadaran memiliki sanitasi, menjaga kesehatan sanitasi, mengubah persepsi masyarakat, dan meningkatkan pengetahuan akan pentingnya dampak serta manfaat yang 
diperoleh dari ketersediaan sanitasi rumah tangga.

\section{Perilaku Masyarakat Terhadap Ketersediaan Sanitasi}

Perilaku rumah tangga berpengaruh terhadap ketersediaan sanitasi, dilihat dari probabiliitas $\mathrm{X}_{3}$ sebesar 0,0003 . Hal tersebut menunjukkan jika perilaku masing-masing rumah tangga yang dapat merawat atau peduli akan kesehatan lingkungan dengan baik maka dapat mempengaruhi setiap rumah tangga untuk memiliki sanitasi semakin berpeluang besar.

Kesadaran akan pentingnya sanitasi bagi masyarakat maupun lingkungan merupakan keadaan optimal pada seseorang yang mana terjadi pemahaman mengenai kesehatan pada diri seseorang. Kesadaran kesehatan perlu ditanamkan sejak dini supaya diharapkan menjadi individu yang peduli akan kesehatan. Jadi kesadaran kesehatan sanitasi menentukan sejauh mana individu mengerti dan memahami mengenai kesehatan baik bagi sosial maupun ekonomi.

Ketersediaan MCK (mandi, cuci, kakus) merupakan bagian dari perilaku hidup sehat, karena MCK sudah menjadi sarana penting untuk melakukan aktivitas rumah tangga setiap hari. Jika masih banyak ditemukan masyarakat yang melakukan perilaku buang air besar sembarangan maka akan mengancam kesehatan yang berpengaruh terhadap kualitas sumber daya manusia.

\section{Hasil Uji Statistik Uji Z}

Uji z merupakan intrumen pengujian yang dilakukan untuk menguji signifikasi pada masing-masing variabel independen terhadap variabel dependen. Kriteria pengujiannya yaitu jika $\mathrm{H}_{0}$ diterima, Ha ditolak (-z tabel $<\mathrm{z}$ hitung $>+z$ tabel). Kemudian jika $\mathrm{H}_{0}$ ditolak, $\mathrm{Ha}$ diterima ( $\mathrm{z}$ hitung $<-\mathrm{z}$ tabel atau $\mathrm{z}$ hitung $>+\mathrm{z}$ tabel).

Sehingga menunjukkan jika hipotesis pengeluaran rumah tangga dengan ketersediaan sanitasi di Kecamatan Suruh Kabupaten Semarang (Ha) diterima dan $\mathrm{H}_{0}$ ditolak, hipotesis informasi kesehatan dengan ketersediaan sanitasi di Kecamatan Suruh Kabupaten Semarang (Ha) ditolak dan $\mathrm{H}_{0}$ diterima, dan hipotesis perilaku masyarakat dengan ketersediaan sanitasi di Kecamatan Suruh Kabupaten Semarang ( $\mathrm{Ha}$ ) diterima dan $\mathrm{H}_{0}$ ditolak.

\section{Likelihood Ratio}

Uji statistika ini untuk mengetahui apakah semua variabel independen di dalam regresi logistik secara serentak atau simultan mempengaruhi variabel dependen sebagaimana uji $F$ di dalam regresi linier. Nilai $-2\left(\mathrm{~L}_{0}-\mathrm{L}_{\mathrm{p}}\right)$ tersebut mengikuti distribusi chi-square dengan $d f=p$. Jika $-2\left(\mathrm{~L}_{0}-\mathrm{L}_{\mathrm{p}}\right) \geq \mathrm{X}_{(\mathrm{p})}^{2}$ atau apabila nilai chisquare hitung $>$ chi-square tabel maka dapat dikatakan bahwa terdapat pengaruh simultan variabel bebas terhadap variabel terikat. Pada hasil regresi logistik menunjukkan dengan $d f=96$ maka LR statistic sebesar $124,0102 \geq 119,87$ sehingga $\mathrm{H}_{0}$ ditolak dan Ha diterima.

\section{Uji Koefisien Determinasi $\left(\mathbf{R}^{2}\right)$}

Pada hasil regresi logistik diperoleh $\mathrm{R}^{2}$ sebesar 0,907416, hal ini berarti 90\% ketersediaan sanitasi rumah tangga di Kecamatan Suruh Kabupaten Semarang dapat dijelaskan oleh variabel independen pengeluaran rumah tangga, informasi kesehatan, dan perilaku rumah tangga. Sedangkan sisanya $10 \%$ dapat dijelaskan oleh variabel-variabel lain diluar model.

\section{SIMPULAN}

Kondisi sosial masyarakat Kecamatan Suruh Kabupaten Semarang yang sebagian besar responden berusia 30-50 tahun jika dilihat dari informasi kesehatan menunjukkan bahwa sedikit masyarakat memperoleh informasi dari petugas kesehatan secara langsung. Perilaku masyarakat yang hampir $50 \%$ dari total keseluruhan responden belum menikmati sanitasi dasar yang layak dan sehat. Kondisi ekonomi di Kecamatan Suruh yang masyarakatnya memiliki mata pencaharian sebagai petani dengan pendapatan yang diperoleh terbatas mempengaruhi pemenuhan kualitas hidup seperti kesehatan, pendidikan, dan sebagainya.

Pengeluaran rumah tangga berpengaruh signifikan terhadap ketersediaan sanitasi. Jika 
pengeluaran rumah tangga dari pendapatan yang diterima masing-masing rumah tangga meningkat maka berdampak kemungkinan ketersediaan sanitasi rumah tangga ikut meningkat. Perilaku masyarakat berpengaruh signifikan terhadap ketersediaan sanitasi. Sedangkan informasi kesehatan tidak berpengaruh signifikan terhadap ketersediaan sanitasi.

Meningkatkan ketersediaan jumlah tenaga profesional yaitu tenaga kesehatan untuk dapat memberikan kontrol pemahaman dan memperbaiki perilaku masyarakat dalam menjaga kondisi lingkungan secara optimal, meningkatkan pendapatan masyarakat dengan peningkatan keterampilan melalui pendidikan non formal sesuai minat dan kemampuan sehingga dapat mempengaruhi pengeluaran rumah tangga Alokasi pengeluaran rumah tangga yang meningkat akan berdampak pada meningkatnya kualitas hidup seperti kesehatan, pendidikan, dan sebagainya. Kemudian yaitu memperluas akses informasi tentang sanitasi kepada masyarakat baik secara formal seperti melalui setiap jenjang pendidikan, maupun non formal (misalnya sosialisasi dengan pendekatan ke kelompok terkecil masyarakat agar dapat lebih intensif dan menyalurkan informasi melalui sarana media elektronik seperti promosi hygiene dan sanitasi).

\section{DAFTAR PUSTAKA}

Badan Perencanaan Pembangunan Daerah. 2013. Buku Putih Sanitasi Kabupaten Semarang Tahun 2013. BAPPEDA, Kabupaten Semarang.

Badan Pusat Statistik. 2015. Data Strategis Kecamatan. BPS, Kabupaten Semarang.

Correa, Javier Santiago Ortiz, et al. 2016. Impact of Access to Water and Sanitation Services on Educational Attainment. Water Resources and Economics, Volume 14, Pages 31-43.

Febriza, Noni dkk. 2015. "Pengaruh Perilaku Hidup Bersih Dan Sehat (PHBS), Pendapatan Dan Sanitasi Terhadap Kejadian Diare Di Keluarahan Meranti Pandak, Rumbai Pesisir Pekanbaru". Dalam Jurnal Ilmu Lingkungan, Volume 9 No. 1. Hal 1978-5283.
Handewi, P.S, Rachman, Supriyati, Benny Rachman. 2002. Struktur dan Distribusi Pendapatan Rumahtangga Petani Lahan Sawah. Laporan Hasil Penelitian Kerjasama Puslitbang Sosial Ekonomi Pertanian dengan BAPPENAS/USAID/DAI.

Hermawan, Yoni. 2005. "Hubungan Antara Tingkat Pendidikan dan Persepsi Dengan Perilaku Ibu Rumah Tangga Dalam Pemeliharaan Kebersihan Lingkungan". Dalam Jurnal Lingkungan Hidup, Volume 5 No. 2. Hal 1411-9668.

Hosmer, D.W dan Lemeshow, S. 2000. Apllied Logistic Regression. John Wiley \& Sons. New York.

http://stbm-indonesia.org/_(diakses pada 4 Februari 2016, pukul 15.00 WIB).

https://www.selasar.com/ekonomi/bukan-sekadarsanitasi (diakses pada 2 Februari 2016, pukul 13.00 WIB).

http://www.unicef.org/indonesia/id/A8__B_Ringkasan_Kajian_Air_Bersih.pdf (diakses pada 2 Februari 2016, pukul 11.00 WIB).

Joko, Tri dan Elanda Fikri. 2012. "Kondisi dan Upaya Strategi Penanganan Sanitasi di Kotas Batam". Dalam Jurnal Kesehatan Lingkungan Hidup, Volume 11 No.1.

Munamati, Muchaneta, et al. 2016. Exploring the determinants of Sanitation Success in SubSaharan Africa. Water research, Volume 103, Pages 435-443.

Notoatmodjo, Soekidjo. 2007. Perilaku Kesehatan dan Ilmu Perilaku. Jakarta: PT. Rineka Cipta.

RAHMAN, Yozi Aulia. Implementasi Program Penanggulangan Kemiskinan Perkotaan (P2kp) Di Kecamatan Tonjong Kabupaten Brebes Tahun 2007. Jejak: Jurnal Ekonomi Dan Kebijakan, [S.1.], v. 3, n. 1, Dec. 2015. ISSN 2460-5123. Available at: $<$ http://journal.unnes.ac.id/nju/index.php /jejak/article/view/4665/3877>.

Zakaria, F, et al. 2015. Decision Support System for the Provision of Emergency Sanitation. Science of the Total Environment, Volume 512523, Pages 645-658. 